\title{
ISLAM DAN TANTANGAN DEMOKRATISASI DI INDONESIA
}

\author{
Abdul Hadi WM \\ Universitas Paramadina Jakarta \\ Email: hadiwm@yahoo.com
}

Abstrak:

\begin{abstract}
Banyak kelompok ummat Islam di Indonesia, yang sebenarnya tidak lagi mempertentangkan Islam dan demokrasi. Namun demikian, masib banyak pula mereka yang mempertentangkan secara nyata bahwa Islam bertentangan dengan demokratsi. Namun demikian harus diakui bahwa warna demokrasi di Indonesia akan sangat kental dengan pandangan religiousitas masyarakatnya. Alternatif bentuk demokrasi mungkinakan terus menimbulkan polemik. Sebagian kelompok. Muslimin babkan hendak meninggalkan sistem demokrasi yang ada dengan konsep khilafah. Kelompok ini "tidak mengakui demokrasi yang sedang berlangsung pada saat ini. Akan tetapi, Indonesia telah berhasil menciptakan sistem ketata negaraan yang demokratis, bahkan, menurut Anwar Ibrabim, lebih baik dari pada pelaksanakaan demokrasi di negara-negara maju tidak terkecuali Amerika Serikat.
\end{abstract}

Kata Kunci: Indonesia, Demokratisasi, Islam

Abstract:

Many Muslim groups in Indonesia, in fact, no longer oppose Islam and democracy. However, there are still many of them who argue that Islam is against democracy. However, it must be admitted that the colors of democracy in Indonesia will be very thick with the views of the people. Alternative forms of democracy may continue to cause polemics. Some Muslim groups may even want an existing democratic system with the concept of a caliphate. This group "does not recognize the democracy that is taking place at this time. However, Indonesia has succeeded in creating a democratic constitutional system, in fact, according to Anwar Ibrabim, it is better than the implementation of democracy in developed countries including the United States.

Keywords: Indonesia, Demokratisasi, Islam

\section{PENDAHULUAN}

Judul di atas tampak jelas memperlihatkan, bahwa dewasa ini, setelah lima belas tahun reformasi, masih muncul sebuah pertanyaan besar, apakah demokratisasi di Inonesia ini telah berjalan sesuai dengan harapan? Pertanyaan yang paling urgen barangkali . Pertama, apakah dengan demokrasi, masyarakat Indonesia yang berdaulat telah benar-benar tercipta. Kedua, apakah corak demokrasi yang sekarang berkembang di Indonesia sesuai dengan harapan kita semua? Sistem demokrasi di suatu bangsa cenderung merupakan hasil interaksi berbagai pemikiran yang tumbuh dalam masyarakatnya. ${ }^{1}$ Kegelisahan para pakar Muslim terhadap tantangan demokratisasi dapat disimak umpamanya Mahmoud Mohamed Toha, dalam karyanya berjudul Ar-Risâlah as-Sâniyah min al-Islâm adalah salah satu ulama yang gelisah memikirkan AlQur'an dan Hadis yang dianggap memiliki kesenjangan cukup luas dengan nilai demokrasi dan egalitarianisme. Buku ini diterjemahkan oleh Dr. Abdullahi Ahmed An-Na îm dengan judul

\footnotetext{
${ }^{1}$ Bandingkan dengan Soehino, "Masa Depan Hukum dan Demokrasi Indonesia Menggagas Paradigma Hukum yang Berdaulat," dalam M. AS. Hikam dkk., Wacana Politik bukum dan Demokrasi Indonesia, (Yogyakarta: Pustaka Pelajar, 1999), 37;M. Dawam Rahardjo, Ensiklopedi Al-Qur an: Tafsir Sosial Berdasarkan Konsep-konsep Kunci, (Jakarta: Paramadina, 1996), 449
} 
The Second Message of Islam atas permintaan Mahmoud sendiri pada tahun 1980. Mereka “ menggugat" diskriminasi gender, perbudaan, dan egalitarian yang diusung syari'ah. Dan mereka menawarkan solusi, yaitu konsep "missi kedua" dari Islam yang dapat menjembatani kesenjangankesenjangan itu. Pandangan ini agaknya utopis, namun itulah salah satu ekspresi kegelisahan.

Muslimin di Indonesia merupakan populasi Muslim terbesar di dunia, oleh karena itu, pertumbuhan demiokrasi yang nota bene hasil interaksi masyarakat dan sharing pemikiran yang panjang oleh karena itu, tumbuhnya demokrasi memperlihatkan keunikan masyarakat negeri kepulauan ini, karena di negara-negara Muslim lain, demikrasi justru semakin dipertanyakan.

Di negara-negara Timur Tengah, demokratisasi yang digaungkan Amerika Serikat di bawah Geroge W. Bush dan Eropa, telah kehilangan momentumnya, karena kebijakan yang pincang. Ketika pemilu dimenangkan oleh FIS di Maroko dan Hamas di Palestina, serta Partai Islam di Turki, tidak didukung bahkan tidak diakui karena programnya tidak sesuai dengan kepentingan Barat. Hamas dibaikot dan dimusuhi karena tidak mengakui keberadaan Israel, tetapi jika parat Likud yang menang di Israel, meskipun mereka tidak setuju "peta jalan ke kemerdekaan" Palestina ala Washington, dianggap wajar karena itulah demokratis, pro-kontra dapat saja diterima. Bahkan, karena gencarnya pemberitaan negatif terhadap Islam, survey menunjukkan sebagai berikut: Over $40 \%$ thinks Islam is a violent religion and over $50 \%$ doesn't see Islam and democration combine. $10 \%$ admit his present life has been affected by incidents caused by Islam.(www.islamreview).

Mayoritas responden tidak mengetahui mengenai hubungan Islam dan nilai-nilai demokrasi. Dan fenomena ini tidak salah karena memang sikap dan pandangan sebagian Muslimin sendiri terhadap demokrasi cenderung menolak atau abai. Tuntutan berdirinya "khilafah" sedunia dewasa ini, contohnya, merupakan sikap pengabaian terhadap demokratisasi, jika tidak dikatakan sebagai penolakan terhadap sistem yang dibangun dewasa ini. Perlawanan sebagian Muslimin terhadap Barat "dengan segala cara" menimbulkan pandangan keliru tentang Islam, cukup mengejutkan, $40 \%$ menganggap Islam sebagai "agama pendukung kekerasan."

Makalah ini akan meninjau bagaimana pandangan Islam mengenai nilai-nilai yang diusung oleh ide dan konsep demokrasi yang telah menjadi wacana dan acuan universal dan bagaimana masa depan demokrasi di Indonesia. Pelacakan ini bermaksud untuk menawarkan satu sistem yang evakuivalen dengan masyarakat Indonesia. Sistem yang akan dicoba untuk ditawarkan adalah sistem demokrasi yang sesuai dengan ajaran Islam. Oleh karena itu, pendekatan yang akan digunakan adalah pendekatan sistem politik Islam (siyasah shar iyyah). ${ }^{2}$ Adapun siyasah syariyyah adalah wewenang penguasa dalam mengatur kepentingan umum dalam negara Islam sehingga terjamin kemaslahatan dan terhindar dari segala kemudaratan, dalam batas-batas dan kaidah umum yang berlaku, sekalipun upaya ini tidak sejalan dengan ijtihad ulama. ${ }^{3}$ Dengan demikian, batasan dalam kajian ini adalah menawarkan sisten demokrasi yang sinergis dengan kaidah-kadah Islam. Karenanya, kajian akan menawarkan satu konsep demokrasi yang mungkin dapat dijadikan alternasi, yaitu "demokrasi keagamaan" (the religio-democracy).

Pertama kali nilai-nilai demokrasi yang ada dalam ajaran Islam diurai untuk melihat duduk perkara konsep yang dianggap dapat mendukung demokratisasi. Kemudian dilanjutkan dengan mengkaji ulang secara selintas wacana demokrasi yang pernah berkembang di Indonesia. Dan akhirnya, demokrasi keagamaan akan dikemukakan untuk dapat dijadikan wacana demokrasi Indonesia yang saat ini sedang ke arah transisi, meskipun secara konstitusional Indonesia telah mempertegas sebagai suatu negara yang demokratis, namun tampak kepribadian bangsa justru mengalami krisis. Liberalisme yang semakin membesar berbenturan dengan sementara kelompok-kelompok Muslim yang semakin mengental menolak wacana liberalis dan pluralis. Penolakan itu muncul, baik dari kelompok

${ }^{2}$ Kajian tentang siyasah shar iyyah, baca Al-Mawardi AlAbkam al-Sultaniyyah, (Beirut: Dar al-Fikr, t.th.); Ibnu Taimiyyah, Siasah Shar iyyah: Etika Politik Islam, (Surabaya: Risalah Gusti, 1995).

${ }^{3}$ Abdul Azis Dahlan (et. al.), Ensiklopedi Hukum Islam, $\mathrm{V}: 1626$. 
"intrenasionalisme" Islam maupun "lokalisme" Islam.

\section{Nilai-nilai Demorasi dalam Islam.}

Demorasi, suatu istilah yang jauh lebih kuno dari kelahiran Islam itu sendiri, yaitu pada masa Yunani kuna. Kata demokrasi, berarti "rakyat berkuasa" atau "government or rule by the people." Asal kata ini dari bahasa Yunani demos berarti rakyat, kratos/kratein berarti kekuasaan/berkuasa. ${ }^{4}$ Dalam Kamus Besar Babasa Indonesia, disebutkan bahwa demokrasi berarti: 1) (bentuk atau sistem) pemerintahan yang segenap rakyat turut serta memerintah dengan perantara wakilnya; pemerintah rakyat: 2) gagasan atau pandangan hidup yang mengutamakan persamaan hak dan kewajiban serta perlakuan yang sama bagi semua warga negara. ${ }^{5}$

Disamping definisi di atas, demokrasi juga dapat diartikan sebagai konsepsi produk manusia yang merelatifkan pandangan dogmatis serta absolut, dan senantiasa mengasumsikan proses tawar-menawar antara manusia secara horizontal. ${ }^{6}$ Selain itu, demokrasi juga sering diartikan sebagai proses pemerintahan yang bermanfaat bagi rakyat, meskipun rakyat tidak ikut dalam pemerintahan. ${ }^{7}$ Dalam konteks negara liberalkapitalis, demokrasi dimaknai dengan pemerintahan yang diselenggarakan dari, oleh, dan untuk rakyat.

\section{Pengertian-pengertian}

tersebut memperlihatkan nilai-nilai, secara garis besarnya dibagi menjadi empat: pertama, kekuasaan berada di tangan rakyat. Kedua, penjabarannya melalui perwakilan atau pilihan rakyat. Ketiga, persamaan hak dan kewajiban. Keempat, perlakuan yang

4 Lihat Miriam Budiarjo, Dasar-dasar Ilmu Politik, (Jakarta: PT Gramedia Pustaka Utama, 1999), 50.

5 Tim Penyusun Kamus Pusat Pembinaan dan Pengembangan Bahasa, Kamus Besar Bahasa Indonesia, Edisi Kedua cet. III (Jakarta: Balai Pustaka, 1994), 220. Lihat juga Triana Rosantini, "Demokrasi," artikel dalam Ensiklopedi Nasional Indonesia, (Jakarta: Cipta Adi Pustaka, 1989), IV :293-294.

${ }^{6}$ Komaruddin Hidayat, Tragedi Raja Midas: Moralitas Agama dan Krisis Modernisme, (Jakarta:Paramadina, 1998),4.

7 Moh Mahfud MD, "Konfigurasi Politik Hukum Pada Era Orde Lama dan Orde Baru," dalam M.AS. Hikam dkk., Wacana Politik. Hukum dan Demokrasi Indonesia, 20. sama bagi semua warga negara. Kelima, relatifisasi dogma-dogma dan ideologi yang bersifat absolut. Keenam pemerintahan yang bermanfaat atau menguntungkan rakyat. Ketujuh, penyelenggaraan pemerintahan demokratis senantiasa membuka iklim check and balance dalam menjalankan kekuasaan serta terjadinya tawarmenawar warga secara horizontal, meskipun, secara alamiah, selalu ada struktur dan stratifikasi sosial. .

Dengan demikian, dapat dilihat apakah demokrasi seirama dengan nilai-nilai Islam atau tidak meskipun merupakan "hasil kreasi manusia." Demokrasi dianggap sebagai kesepakatan di antara orang-orang dalam suatu kawasan dan disepakati untuk dilaksanakan sebagai ideology mereka. Sebab, menurut suatu penelitian yang diselenggarakan UNESCO dalam tahun 1949, maka mungkin untuk pertama kali dalam sejarah demokrasi dinyatakan sebagai nama yang paling baik dan wajar untuk semua sistem organisasi politik dan sosial yang diperjuangkan oleh pendukung-pendukung yang berpengaruh. ${ }^{8}$

Jika demikian halnya, maka demokrasi adalah ideologi. Ideologi bersifat subjektif-normatif dan tertutup. ${ }^{9}$ Dilihat sifat demokrasi yang sedemikian rupa, maka secara diamtral terjadi benturan ideologik antara demokrasi yang dianggap "universal" di satu pihak, dengan nilai-nilai subjektif, cenderung normative dan tertutup pada sisi yang lain. Oleh karena itu tidak heran bila demokrasi universal mandiri tidak memerlukan corak lain yang dimuatkan di dalamnya, misalnya sosialis, terpimpin, Pancasila, dan sebaginya.. Inilah mengapa AS dengan mudahnya "mensetankan" sistem lainnya dan perlu dirubah, jika perlu dengan kekuatan militer, seperti nasib yang menimpa bangsa Irak dewasa ini. ${ }^{10}$ Dan kini mengancam Iran, yang dianggap "Poros Setan (Axis of Evil) bersama Syria dan Korea Utara (yang terakhir ini sekarang hampir menjadi anak manis)."

${ }^{8}$ Miriam Budiarjo, Dasar-Dasar Ilmu Politik, 50

${ }^{9}$ Kuntowijoyo, Identitas Politik Umat Islam, (Bandung : Mizan, 1999), 22 ;idem, “Umat Perlu Perubahan Cara Berpikir," Ummat, No.22, Th.I 29 April 1996,46.

10 Almarhum Nurcholis Majid bereaksi keras atas kebijakan Preside AS George W Bush ketika menginvasi Irak dengan mengatakan, "Sebaiknya Bush dikucilkan dari dunia beradab dan diperlakukan sebagai penjahat perang." 
Di sinilah bangsa Indoensia, terutama Muslim tanah air, perlu mendiskusikan demokrasi, bukan sebagai ancaman atau lawan, melainkan sebagai suatu conditio sine qua non dalam perkembangan budaya manusia yang terkadang harus melihat kembali nilai-nilai universal yang terkandung dalam sumber-sumber Islam sendiri. Demokrasi bukan sebagai "nilainilai setan" yang bersumber dari masyarakat sekuler, melainkan sebagai "hikmah" yang mungkin berguna bagi Muslimin Indonesia dalam kehidupan berbangsa dan bernegara. Namun yang terjadi Umat Islam tanah air terpecah dalam menyikapi demoikratisasi di Indonesia, paling tidak menjadi 4 (empat) kelompok:

Pertama, Kelompok yang melakukan penyesuaian diri secara menyuluruh sehingga menerima sekularisasi. Golongan ini membentuk partai-partai "sekuler," seperti PDIP, Partai Golkar, Partai Demokrat, dan sebaginya.

Kedua, Kelompok yang mengupayakan nilainilai Islam dalam kehidupan berbangsa dan bernegara yang demokratis yang tidak mementingkan simbol-simbol keagamaan. Kelompok ini mendirikan partai-partai PKB, PAN dan sebagainya.

Ketiga, Kelompok yang memperjuangkan Islam melalui sarana demokratis tanpa membuka kelompoknya bagi kelompok-kelompok lain dengan tujuan mendominasi kekuasaan Indoensia. Kelompok ini mendirikan partai-partai Islam yang kensisten dan ekskluisf, seperti PKS, PNU, Partai Kasih Bangsa, dan terakhir PKNU.

Keempat. Kelompok yang memperjuangkan berdirinya "khilafah" dengan terus menerus menunggu perubahan sikap ummat Islam dari menerima sistem yang telah mapan dengan konsep "khilafah" yang "universal." Kelompom terutama ini diwakili oleh HTI. Baik secara eksplisit maupun implisit kelompok kelompok ini menolak sistem lain yang kini berlaku, termasuk demokrasi pasca reformasi.

Bahkan sebagian kelompok menentang konsep demokrasi dengan melancarkan progamprogram yang tidak demokratis, biasanya mewakili sekte atau kelompok marginal dengan aktivitas religio-politik yang ekstrem. ${ }^{11}$

Kendati demikian, dewasa ini, model demokrasi diakui oleh sebagian besar Muslimin Indoensia. Hal terjadi karena demokrasi dianggap sebagai sistem politik paling efektif dan rasional yang mampu melindungi manusia dari penindasan dan eksploitasi manusia lain. ${ }^{12}$ Bahkan terms "demokrasi Islam" telah muncul dalam wacana demokratisasi di tanah air. Tokoh politik Islam Indonesia, Mohammad Natsir memandang demokrasi Islam adalah perumusan kebijaksanaan politik, ekonomi, hukum dan lain-lainnya yang mengacu kepada asas-asas yang telah ditetapkan oleh Al Quran dan Sunnah Nabi. Atau sekurangkurangnya kebijaksanaan-kebijaksanaan itu tidak bertentangan dengan prisip-prinsip doktrin. ${ }^{13}$

Lebih lanjut, dalam sidang konstituante 1957, Natsir menamakan demokrasi dalam Islam dengan istilah "theistic democracy, " yaitu demokrasi yang dilandaskan kepada nilai-nilai ketuhanan. ${ }^{14}$ Cukup mengherankan istilah yang dekemukakan Natsir muncul pada pemikiran seorang politikus Muslim dari Pakistan, Abu al-A 'la al-Maudud.i ${ }^{15}$ Ia memperkenalkan model demokrasi Islam yaitu "Theo-Demokration," yaitu suatu sistem pemerintahan demokrasi ilahi, karena di bawah naungannya kaum Muslim telah dibagi kedaulatan rakyat yang terbatas di bawah pengawasan Tuhan. ${ }^{16}$

Menurut Yusri Ihza Mahendra, sistem demokrasi yang dikemukakan oleh Maududi adalah a divine democratic government (pemerintah

${ }^{11}$ Jhon L. Esposito dan Jhon O. Voll, Demokrasi di Negara-Negara Muslim, (Bandung: Mizan, 1999), 12.

${ }^{12}$ Baca Umaruddin Masdar, Membaca Pikiran Gus Dur dan Amin Rais Tentang Demokrasi, (Yogyakarta: Pustaka Pelajar, 1999), 106-107.

13 Yusril Ihza Mahendra," Modernisme Islam Dan Demokrasi: Pandangan Politik Muhammad Natsir, “ Islamika, No. 3 Januari-Maret (1994), 70.

${ }^{14} \mathrm{Ibid}$

15 Untuk biografi Abu al-`Ala al-Maududi dan pemikirannya, baca Seyyed Vali Reza Nasr, "Maududi dan Jama 't-i-Islami: Asal Usul, Teori dan Praktek Kebangkitan, dalam Ali Rahmena (ed.), Para Perintis Zaman Baru Islam, (Bandung: Mizan, 1996),101-125; H.A. Mukti Ali, Alam Pikiran Islam Modern di India dan Pakistan, cet.III (Bandung: Mizan, 1998), 238-264..

16 Abu al-'Ala Al-Maududi, Hukum dan Konstitusi : Sistem Politik Islam, Cet. VI (Bandung: Mizan, 1998), 159160. 
yang berdasarkan ketuhanan). ${ }^{17}$ Bahkan Ahmad Syafii Maarif melihat bahwa umat Islam Indonesia, modernis dan sayap pesantren, telah memilih sistem politik demokrasi. ${ }^{18}$

Menurut almarhum Nurcholish Majid, yang ingin dituju dan sistem demokrasi Islam adalah pelaksanaan ajaran-ajaran Islam secara utuh dan konsekuen sehingga menciptakan suatu kemaslahatan sebagaimana yang dicita-citakan siyasah ash-syar'iyyah. ${ }^{19}$ Untuk merealisasikan demokrasi tersebut, Kuntowijoyo menawarkan enam kaidah-kaidah demokrasi yakni : 1) ta aruf (saling mengenal); 2) shura (musyawarah); 3) taiawn (kerja sama); 4) maslabah (menguntungkan masyarakat), 5) 'adl (adil); 6) tagyir (perubahan). ${ }^{20}$ Selain kaidah-kaidah tersebut, baru-baru ini Mohammed Arkoun 21 mengemukakan bahwa munazarah (tukar pikiran) adalah jantung demokrasi, karena dalam munazarah setiap orang bebas mengeluarkan pendapatnya. ${ }^{22}$

Namun demikian, dari ketujuh kaidah-kaidah (plus kaidah Arkoun), hemat penulis, muara dari demokrasi dalam Islam adalah terciptanya kemaslahatan. Oleh karena itu, jika keenam (minus maslahah) tercapai, akan tetapi kemaslahatan tersebut belum tercipta maka negara tersebut belum melaksanakan demokrasi. Untuk itu, kirannya penting untuk dijelaskan apa yang dimaksud dengan maslahah dalam sistem politik Islam.

17 Yuzril Ihza Mahendra, Modernisme dan Fundamentalisme Dalam Politik Islam, 246.

18 Ahmad Syafii Maarif, Islam dan Masalah Kenegaraan, 125.

${ }^{19}$ Kajian terkini mengenai cita-cita politik Islam, baca Nurcholish Madjid, Cita-Cita Politik Islam Era Reformasi, (Jakarta : Paramadina, 1999).

${ }^{20}$ Baca penjelasan mengenai keenam kaidah tersebut dalam Kuntowijoyo, Identitas Politik Umat Islam, 91-105. Disamping Kuntowijoyo, sebagai referensi lanjutan baca M. Quraish Shihab, Wawasan Al-Quran: Tafsir Maudu $i$ atas Pelbagai Persoalan Umat, (Bandung: Mizan, 1999), 469-485; Abdul Azis Dahlan (et.al.), Ensiklopedi Hukum Islam, IV $: 1264$.

${ }^{21}$ Muhammad Arkoun adalah seorang pemikir Islam, kontemporer, mengenai biografinya baca: Suadi Putro, Mubammed Arkoun Tentang Islam dan Modernitas, (Jakarta : Paramadina, 1998).11-26.

${ }^{22}$ Lihat Mohammed Arkoun: Kejayaan Islam Melaui Pluralisme Pemikiran, "Kompas, 1 April (2000),1 dan 11.
Istilah maslahah, yang antara lain menurut Imam al-Ghazali (w.1111) dan Jalal al-Din alSayuti, dar'u 'l-mafasid jalb al-masalih yang bermakna mengambil manfaat dan menolak kemudaratan dalam rangka memelihara tujuan syarak..$^{23}$ Definisi ini sejalan dengan definisi siyasab syariyyah di atas, dengan demikian, aktivitas politik dalam Islam, baik itu demokrasi atau selainnya, sejatinya menjiwai maslahat tersebut.

Karena itu konsep maslahat merupakan titik kendali dalam perilaku politik Islam. Menurut Ali Yafie, ${ }^{24}$ dalam kajian abl al-Ijtihad ada tiga jenis maslahah yaitu: ${ }^{25}$

1. Maslahah yang diakui ajaran syari 'ah, yang terdiri dari tiga tingkat kebutuhan manusia, yaitu:

a. Daruriyyah (bersifat mutlak) karena menyangkut komponen kehidupannya sendiri sebagai manusia, yakni hal-hal yang menyangkut terpeliharanya dirinya (jiwa, raga, dan kehormatannya), akal pikirannya, harta bendanya, nasab keturunannya dan kepercayaan keagamaannya. Kelima tersebut biasanya disebut al-kulliyyat alkhams atau al-daruriyyat al-khams, yang menjadi dasar maslahah (kepentingan dan kebutuhan manusia)

b. Haijiyyah (kebutuhan pokok) untuk menghindarkan kesulitan dan kemelaratan dalam kehidupannya.

c. Tahsiniyyah (kebutuhan pelengkap) dalam rangka memelihara sopan santun dan tata krama dalam kehidupan.

2. Maslahah yang tidak diakui ajaran syariah, yaitu kepentingan yang bertentangan dengan maslahah yang diakui terutama pada tingkat pertama.

23 Al-Gazali, Al-Mustasfa fi al-usul. (Bairut: Dar alFikr). Al-Sayuti alAsybah wa an-naza'ir. Abdul Azis Dahlan (et.al.), Ensiklopedi Hukum Islam, IV :1143.

${ }^{24}$ Ali Yafie adalah penggagas fiqh sosial. Untuk kajian pemikirannya baca Jamal D. Rahman et.al.(eds.), Figh Sosial: Wacana Baru 70 Tabun K.H. Ali Yafie, (Bandung:Mizan, 1997).

${ }^{25} \mathrm{KH}$. Ali Yafie, 'Konsep-konsep Istihsan, Istislah dan Maslahat Al-Ammah," dalam Budhy MunawarRachman (ed), Kontektualisasi Doktrin Islam dalam Sejarah, cet.II (Jakarta: Paramadina, 1995). Jika ingin mendalami tentang maslahat baca Muhammad Khalid Masud, Filsafat Hukum Islam, (Bandung: Pustaka 1996). 


\section{NUSANTARA; Journal for Southeast Asian Islamic Studies}

Vol. 16, No. 1, Juni 2020

3. Maslahah yang tidak terikat pada jenis pertama dan kedua.

Sistem demokrasi sangat relevan dengan tujuan-tujuan syari'ah, sebagaimana tersebut di atas yang juga dikemukakan oleh al-Syatibiy dalam kitabnya al-Muwafaqat. Bahkan ia menegaskan bahwa maqasid al-syari'ah tersebut merupakan kebutuhan dasar manusia secara universial tanpa melihat lata belakang suku, ras dan agama. Sedemikian strategisnya pengetahuan mengenai tujuan syari'ah sehingga Imam alHaramain al-Juwainiy mewngatakan orang yang tidak mengetahui tujuan syari'ah tidak berhak memutuskan suatu hukum syar'iy.

Sementara itu, mengenai sesuatu dapat dikatakan maslahah, sebagaimana ditulis Amir Mu`alim dan Yusdani dalam buku Konfigurasi Pemikiran Politik Islam, dengan mengutip pendapat Prof.al-Buti, menyatakan bahwa ada lima criteria dalam menentukan kemaslahatan, yaitu: a) memprioritaskan tujuan-tujuan Syara` (syariat); b) tidak bertentangan dengan Al Qur`an; c) tidak bertentangan dengan al-Sunnah; d) tidak bertentangan dengan prinsip Qiyas; e) memperhatikan kemaslahatan yang lebih penting (besar). ${ }^{26}$

Demikianlah nilai-nilai demokrasi dalam Islam. Apa yang ingin dikatakan adalah bahwa dalam Islam, kelengkapan dasar-dasar demokrasi telah diatur sedemikian rupa. ${ }^{27}$ Namun pada dataran aplikasi, nilai-nilai tersebut tidak diterapkan secara benar dalam kehidupan suatu bangsa. Tambahan lagi, bahwa selama ini, konsep-konsep Islam tentang demokrasi cenderung hanya pada dataran ide pada gilirannya menyebabkan polemik yang tidak pernah selesai. ${ }^{28}$ Akibatnya, seolah-olah Islam tidak mempunyai demokrasi yang jelas. Sehingga, banyak negara yang mayoritas penduduknya Muslim tidak tidak

26 Amir Mu'allim dan Yusdani, Konfigurasi Pemikiran Hukum Islam, (Yogyakarta: UII Press, 1999),39-41.

${ }^{27}$ Bandingkan dengan Teuku May Rudy,"Politik Islam Dalam Pemerintahan Demokrasi," dalam Abu Zahra, Politik Demi Tuhan: Nasionalisme Religius di Indonesia, (Bandung: Pustaka Hidayah, 1999), 361-366.

28 Diskusi menarik tentang hal ini, baca Masykuri Abdillah, Demikrasi di Persimpangan Makna: Respons Intelektual Muslim Indonesia Terhadap Konsep Demokrasi (19661993), (Yogyakarta: Tiara Wacana, 1999). menjadikan Islam sebagai landasan demokrasinya. Contoh konkritnya yaitu Indonesia.

Masalah fundamental demokrasi dalam pandangan Islam adalah pendewaan, pengabdian, dan pemutlakan terhadap manusia sendiri yang dituangkan ke dalam deklarasi HAM, itu berarti meletakkan kedudukan yang sama secara mutlak antara Muslim dan non-Muslim. Ini berarti pula telah menodai supremasi Muslim atas lainnya dalam negerinya sendiri.

Selisih pemahaman ini seolah-olah sebagai penegasan wacana "benturan budaya" paparan Samuel P. Huntington dalam bukunya"Religion in the Third Wave," National Interest (1991), Although Islam is one of the socio-cultural element of our country but may it plays the role of law and values of Indonesia nation life. For the Indonesian Muslim political weakness, may be, their political concept and praxis just colored by cultural attempt like grasped in Kuntowijoyo`s notions, not structural and constitutional work. Konsep politik Islam sangat berbeda dan bertentangan dengan permis-premis demokrasi politik. Bahkan dalam tulisan kontriversial lainnya yang diberi judul "The Clash of Civilization?" yang dimuat di journal Foreign Affair (1993) ia menegaskan, that West will be in confrontation with Islam in the future. ${ }^{29}$ Para pemikir Barat seperti John L. Esposito, John O. Voll, James Piscatory dan lain-lain terpana dan uring-uringan ketika dua gedung WTC dihancurkan pada tanggal 11 September 2001 oleh al-Qaidah. Pada hal mereka selalu memiliki pandangan netral terhadap Islam karena itu menentang pandangan Hantington di atas. Bagi pemikir ini demokrasi bersifat universal yang dapat diinterpretasikan ke dalam inti ajaran Islam sebagai agama dan ediologi. Tetapi kasus tersebut bukan berarti mereka harus merevisi pandangannya terhadap Islam. Karena al-Qaidah, Jamaah Islamiyah, atau apapun lainnya, meskipun mengklaim Islam, tentu tidak dapat dikatakan benar-benar mewakili Islam.

Maududi setuju dengan tiga pembagian kekuasaan (trias politica), judikatif, legislatif, dan eksekutif tetapi ketiga-tiganya harus berada di bawah naungan Al-Qur'an. melihat, kekuasaan

29 M. Syâfìi Anwar, "Pemikiran Politik dengan Paradigma Al-Quran" in Kuntowijoyo, Identitas Plitik Umat Islam, xxii. 
bukanlah dipegang oleh rakyat, melainkan oleh Tuhan. Namun ia menganggap bahwa anggota legislatif haruslah abl al-ball wa 'l-'aqd (para ulama). Kelompok minoratas non-Muslim yang duduk di dalam dewan perwakilan tidak berhak menentukan kebijakan negara selain kepentingan mereka.

Pancasila dan UUD 1945 yang menjamin kebebasan beragama (pasal 29). Notonegoro dari Universitas Gajah Mada seperti kata Kuntowijoyo, mengatakan, bahwa Pancasila dapat disebut monodualism, yaitu sebuah kombinasi dari nilai-nilai spiritual dan tuntutan kepuasan material. Bahkan Kuntowijoyo mengusulkan, sebuah istilah theodemocration (demokarasi ilahi) bagi sistem demokrasi di Indonesia.. yaitu suatu "kekuasaan yang dilaksanakan" oleh Tuhan dan manusia. Meskipun terdiri atas dua kalimat yang terdiri atas kata theos dan demons, sebagaimana diistilahkan dalam budaya Jawa loro-loroning atunggal, secara aktual dijabarkan dalam satu nafas (the one breath pulling) "theodemocration." Sebagaimana Maududi, ia menolak istilah ini diidentikkan dengan konsep Barat "theocracy." Namun menurut mereka dalam seting kata theokrasi atau teosentrisme $\sim$ disebut taubid dalam doktrin Muslim $\sim$ merupakan kedaulatan Tuhan dalam sebuah negara. Manusia sekedar khaliffah di bumi yang bertanggung jawab kepadaNya. Kekuasaan yang berada di tangan manusia merupakan amanah. Postulasi vox populi vox dei di Indonesia agaknya difahami bahwa suara rakyat menentukan kebijakan negara namun bukan sebagai pengganti wisdom dari Allah Swt. Apa yang terbatas tidak menggantikan Ketidakterbatas. ${ }^{30}$

Sebuah upaya elaborasi sinergik harus segera dibuat untuk menyelaraskan konsep Ketuhanan Yang Maha Esa dan pemikiran tentang "God Sovereignty", meskipun harus mengacu pada sudut pandang ke-Indonesia-an. Allah Swt sendiri tampak memprioritaskan jamaah dan jamaah tentu merupakan kesepakatan yang muncul dari pandangan-pandangan individual yang telah mengkristal.

Dalam era multi partai pasca reformasi dan demokratisasi yang memunculkan penguatan sipil dalam kekuasaan negara, suka atau tidak suka hukum privat dan hukum publik harus disesuaikan dengan aspirasi masyarakat yang berkembang. Bangsa Indonesia yang sering disebut sebagai bangsa religious, di mana rakyat mayoritas beragama Islam maka nilai-nilai yang dibawa oleh Islam tentu akan banyak berpengaruh dalam pembentukan kepribadian Indonesia. Amin Rais pernah berkata, demokrasi adalah demokrasi. Konotasi atau terma lain tidak perlu dikombinasikan dengan demokrasi. Namun Muslimin sebagai penduduk mayoritas tidak dapat menerima kensep hukum, etik, moral, dan politik sekuler. Pada Konggres Umat Islam, 3 November 1989, Amin mendesak bahwa demokrasi di Indonesia harus di bawah bimbingan sinar wahyu..

\section{Kesimpulan}

Demokratisasi di Indonesia ditanggapi secara beragam oleh kelompok-kelompok ummat Islam Indonesia, namun secara umum, atau katakanlah mayoritas Muslimin Indonesia tidak mempertentangkan atau menolak demokratisasi. Namun meskipun begitu harus diakui bahwa warna demokrasi di Indonesia akan sangat kental dengan pandangan religiousitas masyarakat Indonessia. Alternatif bentuk demokrasi mungkinakan terus menimbulkan polemik. Sebagian kelompok Muslimin bahkan hendak meninggalkan sistem demokrasi yang ada dengan konsep khilafah. Kelompok ini "tidak mengakui demokrasi yang sedang berlangsung pada saat ini. Kelompok Syi'ah juga tentu berbeda, karena demokrasi menyamaratakan hak menjadi Presiden atau kepala negara bagi setiap warga yang memenuhi syarat. Bagi mereka yang memenuhi syarat hanyalah ahlul bait. Yang jelas Indonesia telah berhasil menciptakan sistem ketata negaraan yang demokratis, bahkan, menurut Anwar Ibrahim, lebih baik dari pada pelaksanakaan demokrasi di negara-negara maju tidak terkecuali Amerika Serikat.

${ }^{30}$ Kuntowijoyo, Identitas Politik Umat Islam (Bandung: Mizan, 1997), p.p. 60, 1. 


\section{DAFTAR PUSTAKA}

Abdullah, M. Amin, "Relevansi Studi AgamaAgama dalam Lingkungan Millenium Ketiga (mempertimbangkan kembali Metodologi Filsafat Keilmuan Agama dalam upaya memecahkan persoalan keagamaan kontemporer)," dalam Ulumul Qurian, No. 5 VII/ (1997), pp. 56-68.

Abdillah, Masykuri. Demokrasi di Persimpangan Makna: Respons Intelektual Muslim Indonesia Terbadap Konsep Demokrasi (1966-1993). Yogyakarta: Tiara Wacana, 1999.

Al-Maududi, Abul 'Ala. Hukum dan Konstitusi : Sistem Politik Islam, cet. VII Bandung: Mizan, 1998.

Ali, Mukti. Alam Pikiran Islam Modern di India dan Pakistan, cet. III Bandung : Mizan, 1998.

Al-Mawardi. Al-Abkam al-Sulthaniyyah Beirut: Dar al-Fikr, t.th.

Budiarjo, Miriam. Dasar-Dasar Ilmu Politik. Jakarta: PT Gramedia Pustaka Utama, 1999.

Dahlan, Abdul Azis (et.al.). Ensiklopedi Hukum Islam. Jakarta : Ichtiar Baru van Hoeve, 1996.

Esposito, Jhon L.dan O.Voll. Demokrasi di NegaraNegara Muslim. Bandung : Mizan, 1999.

Hidayat Komaruddin. Tragedi Raja Midas: Moralitas Agama dan Krisis Modernisme. Jakarta: Paramadina, 1998.

Kuntowijoyo. Identitas Politike Umat Islam. Bandung : Mizan, 1999.

"Umat Perlu Perubahan Cara Berpikir," dalam Ummat, No.22, Th. I 29 April 1996.

Maarif, A. Syafii. Islam dan Masalah Kenegaraan: Studi tentang Percaturan dalam Konstituante. Jakarta : LP3ES, 1996.

Madjid, Nurkholish, Cita-Cita Politike Era Reformasi, Jakarta: Paramadina, 1999.
Mahendra, Yusril Ihza, 'Modernisme Islam dan Demokrasi : Pandangan Politik Mohammad Natsir," dalam Islamika. No. 3 Januari-Maret (1994), pp. 64-73.

Masdar, Umaruddin. Membaca Pikiran Gus Dur dan Amin Rais tentang Demokrasi. Yogyakarta : Pustaka Pelajar, 1999.

Masud, Muhammad Khalid. Filsafat Hukum Islam. Bandung: Pustaka, 1996.

Mahfud MD, Moh. "Konfigurasi Politik dan Hukum Pada Era Orde Lama dan Orde Baru," dalam M. AS. Hikam dkk. Wacana Politik Hukum dan Demokrasi Indonesia. Yogyakarta: Pustaka Pelajar, (1999). Pp. 18-34.

Mu`allim, Amir dan Yusdani. Konfigurasi Pemikiran Hukum Islam. Yogyakarta: UI Press, 1999.

Nasr, Seyyed Vali Reza, “Maududi dan Jama't-iIslami: Asal Usul, Theoridan Praktek Kebangkitan, dalam Ali Rahmena (ed.). Para Perintis Zaman Baru Islam. Bandung : Mizan, (1996). pp.101-105.

Rudy, Teuku May. "Politik Islam dalam Pemerintahan Demokrasi," dalam Abu Zahra. Politik Demi Tuhan: Nasionalisme Religius di Indonesia. Bandung: Pustaka Hidayah, (1999), pp. 293-294.

Shihab, M. Quraish. Wawasan Al-Quran: Tafsir Maudhu'I atas Pelbagai Persoalan Umat. Bandung: Mizan, 1999.

Soehino, 1999, "Masa Depan Hukum dan Demokrasi Indonesia Menggagas Paradigma Hukum yang Berdaulat," dalam M. AS. Hikam dkk. Wacana Politik Hukum dan Demokrasi Indonesia. Yogyakarta: Pustaka Pelajar, 1999. pp.35-53.

Yafie, KH. Ali, "Konsep-Konsep Istihsan, Istihlah dan Maslahat Al-Ammah," dalam Budhy Munawar-Rachman (ed). Kontekstualisasi Doktrin Islam dalam Sejarah, cet.II Jakarta: Paramadina. (1995), pp.362-368. 